\title{
Stem Cells and Cardiac Disease: Where are We Going?
}

\author{
Beatriz Pelacho and Felipe Prosper*
}

\begin{abstract}
Hematology and Cell Therapy, Clínica Universitaria and Division of Cancer, Foundation for Applied Medical Research, Division of Cancer, University of Navarra, Pamplona, Spain
\end{abstract}

\begin{abstract}
During the last 10 years we have witnessed the development of a new field in research termed Stem Cell Therapy. Classically, it was considered that cells had a limited division and differentiation ability; however, this dogma was challenged when new exciting results about cell multi/pluripotency were presented to the scientific community. It was found that cells from one adult tissue source were able to originate cells of a very different type. The possibility of transplanting these cells into damaged organs with the aim of substituting sick or dead tissue, triggered many studies to understand the plasticity of the stem cells and their potential in pathological situations. Nowadays, much more is understood about stem cells, although of course, many questions, especially about their mechanism of action, still need to be answered. Their benefit after transplantation has been shown experimentally and even clinically in some cases; however, the degree of stem cell contribution through their own differentiation into the transplanted tissue, has turned out to be generally low, and increasing evidence indicates that a trophic effect must play an important role in such a benefit. A better understanding of the paracrine mechanisms involved could be of great relevance in order to develop new therapies focused on stimulating endogenous cells. On the other hand, more sophisticated methods for cell transplantation combined with bio-engineering techniques have been devised in cardiac disease models. In this review we will try to provide a critical overview of the stem cell studies performed until now and to discuss some of the questions raised about the mechanisms that are involved in their putative reparative effect in cardiovascular diseases, and their origin.
\end{abstract}

\section{INTRODUCTION}

The presence of progenitor cells with the ability to replace senescent tissues in the different organs was reported some time ago; however, this potential was believed to be restricted to certain tissues, and only during the last few years has the existence of rare cell populations with multipotent or even pluripotent capabilities been described in most adult tissues. Such findings have been especially striking in organs like the heart and the brain, which were typically considered organs with extremely low self-renewal capacity, consisting of cardiomyocytes (CMs) and neurons classically considered cells that lose their potential to proliferate right after birth. However, although the presence of progenitors with a proliferative and differentiation capacity has been shown, unfortunately, in the case of severe diseases like myocardial infarction (MI) or stroke, their potential seems not to be sufficient to restore a damaged organ. A deeper understanding of the origin and "behavior" of these stem cells is mandatory to be able to manipulate them and induce their activation and differentiation to regenerate the damaged tissues.

Although the risk of death in patients with myocardial infarction during the acute stage has been significantly diminished, this has brought about an increased incidence of chronic heart problems. Drug treatments can only partially improve the patient's quality of life and cannot counteract the adverse remodeling processes that take place after acute infarction. As consequence of the ischemia, a progressive contractile dysfunction of the viable myocardium will follow which will end up in many cases in heart failure [1]. Taking

*Address correspondence to this author at the Hematology and Cell Therapy, Clínica Universitaria, Av Pío XII 36, Pamplona 31008, Spain;

Tel: +(34)-948-255-400; E-mail: fprosper@unav.es these aspects into account, an ideal therapy should be able to regenerate the damaged tissue providing new cells, which ideally could be applied during the first stages of the diseases with the aim of reversing the initial damage and controlling the remodeling processes initiated as a consequence of the acute ischemia.

In this article, we will review the potential of the different types of stem cells identified until now, focusing on their in vitro capacity to differentiate to mesoderm-derived cells like CMs and vascular cells, and therefore, their application in animal models of myocardial infarction. Finally, we will describe and discuss some of the more relevant clinical trials in the field of cardiac diseases.

\section{STEM CELLS AND CARDIAC DISEASE}

The replacement of the dead tissue in the ischemic heart by new CMs (and vascular cells) has become one of the main objectives of stem cell therapy in cardiac disease. In general, it has been demonstrated that stem cells can be manipulated in vitro to differentiate into different mesodermal cell types, which express tissue specific markers and in some cases, functionally behave like them. Thus, the embryonic stem cells (ESCs), which are isolated from the inner cell mass of the embryo, are the cells with the greatest differentiation potential, since it is possible to derive them to all somatic and germinal tissues. A number of studies performed with mice and human ESCs have addressed the basic signaling mechanisms involved in tissue development but also the potential to manipulate them in vitro and in vivo for tissue regeneration [2]. On the basis of these studies and knowledge about embryo development, the differentiation potential of the adult stem cells (SC) has also been broadly tested. The cardiac (and vascular) differentiation potential of embryonic 
and adult stem cells and their regeneration capability in animal models of cardiac ischemia will be discussed next.

\section{Stem Cell-Based Experimental Studies}

\section{Embryonic Stem Cells (Escs)}

The in vitro ESC differentiation potential towards cells belonging to the three germ layers is well described. ESCs differentiate into CMs (reviewed in [3] and [4]) by culturing in suspension as embryoid bodies followed by plating them a few days later. Although there is a high variability rate, spontaneous differentiation with beating areas can be generally detected [5]. Also, their co-culture with the primary visceral endoderm cell line END-2, gives a successful differentiation [6]. Importantly, not only specific cardiac proteins expression but also electromechanical coupling and electrophysiologic specialization can be detected $[5,7,8]$. Furthermore, their cardiomyogenic potential has been confirmed in vivo when transplanted, after in vitro differentiation, into ischemic hearts $[9,10]$. However, it seems that no specific directed cardiac differentiation occurs in the heart. Thus, when undifferentiated human ESCs are injected in the hind limb they give rise to the same proportion of cardiomyocytes as when they are injected in the heart [11]. Besides, teratoma formation has been detected in all cases. The high risk of tumor formation makes it mandatory to pre-differentiate the cells towards CMs and to develop techniques to isolate a highly purified population of CMs. Importantly, it has been shown that ESC-derived CMs are terminally differentiated cells that are functionally equivalent to $\mathrm{CMs}$ isolated from the heart (reviewed in [12]). Unlike mouse ESCs, human ESCs possess a certain degree of proliferation in vitro $[13,14]$ and in vivo [9]. Thus, the cells can be expanded and differentiated in bio-reactors and genetically selected by using transgenes encoding fluorescent reporters or antibioticresistance genes controlled under a cardiac-specific promoter [15-18]. These strategies have been shown to produce almost pure CMs that once transplanted into the heart do not seem to form tumors; however, these genetic approaches present many obvious restrictions to their clinical application. On the other hand, interesting experiments have been performed by the groups of Terzic [19] and Murry [20], in which ESC cardiac specification was guided by specific cytokine treatment (TNF- $\alpha$ or Activin-A plus BMP4 combination respectively), and a pure cardiac population was obtained that, once transplanted in the infarcted heart, is able to partially regenerate the muscle with no tumor formation reported. Furthermore, these cells positively affected cardiac performance and also, when transplanted with a cocktail of pro-survival cytokines, induced a significantly greater improvement of cardiac function [20]. A caveat to these results is provided by a recent study published by Mummery's group, which shows that transplantation of human ESC derived CMs in a mouse model of MI induced an improvement in cardiac function (together with cell engraftment); however, this effect disappeared at 3 months [21]. Thus, long-term studies need to be performed in order to determine the safety and efficacy of ESCs. Finally, another major issue that needs consideration together with the tumorigenic potential is the immune rejection provoked by the ESCs. Nuclear transfer in order to obtain non-immunogeneic patient-matched ESCs, creation of hematopoietic cells lines derived from human ESCs or expression by the ESCs of recipient specific majorhistocompatibility complex molecules, are some approaches that are being studied.

\section{Bone Marrow-Derived Sc}

In adult tissues, stem cells with differentiation potential have been found, albeit with a more limited than ESCs. However, the in vitro differentiation potential of Bone Marrow (BM)-derived cells towards CMs is not yet clear. Early studies performed by Fukuda et al. showed differentiation of BM-derived stromal cells towards spontaneous contractile cells with cardiac phenotype when treated with 5-Azacitidine [22]; however, subsequent studies showed that the differentiated cells also expressed skeletal myoblast markers. Moreover, other laboratories have not been able to reproduce these experiments. In vivo, however, although the degree of differentiation still remains controversial, many reports have shown cardiac differentiation potential from BM-derived cells. This evidence was supported by human sexmismatched heart transplantation, where cardiac chimerism was determined in transplanted patients [23-26]. The percentage of contribution however, was very low in all these cases $(0.02 \%$ to $0.07 \%)$ which raised questions about the physiological relevance of their contribution. On the other hand, a higher differentiation rate to endothelial cells was found.

In one of the first studies performed in a murine model, GFP positive BM-derived hematopoietic cells were transplanted into a lethally irradiated mouse model of acute MI. As a result of the transplantation, only a very low rate of $\mathrm{GFP}^{+} \mathrm{CMs}(\approx 0.02 \%)$ were found in the perinfarct region (and 3.3\% of endothelial cells) and importantly, it was proven that such cell plasticity could be due to a fusion phenomenon [27,28]. On the other hand, studies from Anversa's group have shown that transplantation of the BM fraction $\mathrm{Lin}^{-} / \mathrm{ckit}^{\text {high }}$ in the infarcted myocardium, could contribute to nearly $50 \%$ of de novo CMs, endothelial and smooth muscle cells [29]. Unfortunately, these experiments have not been reproduced by other independent laboratories using similar or even the same models, leading to a general skepticism regarding the potential of BM cells to differentiate into functional cardiomyocytes [30,31]. Some interesting studies have been performed with heterozygous cKit mutant mice $\mathrm{Kit}^{\mathrm{W}} / \mathrm{Kit}^{\mathrm{W}-\mathrm{V}}$ [32]. When MI was provoked, the abnormality led to dilated cardiomyopathy and death from cardiac failure but failing hearts could be rescued by transplantation of wild type BM cells. Although an angiogenic positive effect of the cKit cells was demonstrated, no cKit-derived cardiomyocytes were found. Further studies are needed in order to better understand the role of the $\mathrm{cKit}^{+}$cells in cardiac regeneration. On the other hand, the existence of rare cell populations in the BM with much higher differentiation capability has recently been demonstrated. MAPCs were the first cells described with the capability to give rise to cells derived from the three germinal layers [33,34]; subsequently, other cells like the MIAMI [35], VSEL [36], SSEA1+ [37], Oct4+ [38] and SSEA1+ and SSEA3+ BM-derived clonal cells [39] have also been described. More detailed molecular studies need to be performed in order to determine whether these putative different cell types represent the same population at 
different differentiation stages. It has been demonstrated that some of these populations possess cardiac potential, like the VSEL cells [40] or the ones described by the group of Losordo [39], which have been demonstrated to contribute in vivo to $\mathrm{CMs}(4.1 \% \pm 3.1 \%$ in the peri-infarct region $)$ together with endothelial and smooth muscle cells $(5.4 \% \pm 3.3 \%$ and $5.8 \% \pm 2.9 \%$ respectively), and which induced a favorable remodeling and improvement in the cardiac function of the ischemic heart. An augmentation of proliferation and preservation of the perinfarcted area at risk by up-regulation of paracrine factors involved in angiogenesis, apoptosis and proliferation, was also demonstrated. Interestingly, these cardiac cells were negative for the cKit marker. Also, the pluripotent BM-derived SC population MAPCs, was tested as a candidate for cardiac repair in acute and chronic infarct. Although cardiac differentiation was not proven due to rapid disappearance of the transplanted cells (probably due to the ischemic conditions of the tissue and immunological reaction against the non-host GFP or $\beta$-galactosidase cell markers), improvement of the cardiac function, which was not achieved in the control group transplanted with BM cells, was demonstrated $[41,42]$. In the acute model, a reduction of the infarct size and induction of the neoangiogenesis was shown. In vitro analysis showed that MAPCs could have had a trophic effect by secretion of inflammatory (monocyte chemoattractant protein-1 (MCP)-1) and angio/arteriogenic (VEGF, platelet derived growth factor (PDGF)-BB, and TGF- $\beta 1$ ) factors, together with an anti-apoptotic protective effect of the myocardium at risk. Importantly also, differentiation towards endothelial (venous or arterial) and smooth muscle cells has been demonstrated in vitro and in other in vivo ischemia models $[43,44]$.

\section{Adipose-Derived Sc (Adsc)}

The adipose tissue, like the BM, contains a population of cells that has extensive self-renewal capacity, its expansion being not only due to mature adipocyte hypertrophy but also to the presence of precursor cells in the stroma-vascular fraction (SVF). Planat-Benard et al showed that this particular cell fraction was able to rescue lethally irradiated mice as consequence of reconstitution of the major hematopoietic lineages [45]. Furthermore, it was shown that the ADSCs could differentiate not only into hematopoietic cells but also into mesenchymal cell types (osteoblasts and adipocytes), and most importantly, into vascular endothelium [46] and cardiac-like cells [47]. Thus, when fresh SVF are cultured in methylcellulose, they become organized forming contractile clumps which contain cardiac cells with ventricle- and atriallike phenotype. Importantly, electrophysiological studies performed on early cultures revealed a pacemaker activity of the cells. Moreover, stimulation by adrenergic or cholinergic agonists in more mature differentiated cells was detected. Similarly, cultured cells could give rise to endothelial cells whose beneficial effect has been demonstrated in vivo by their contribution to neoangiogenesis in hindlimb ischemia mice models [48] and by their ability to secrete angiogenic and antiapoptotic factors [49]. On the other hand, ADSC cardiac differentiation has been recently demonstrated when transplanted in acutely infarcted mice [50], and an improvement in the cardiac function has been proven after CD29+ SVF cell transplantation [51]. Importantly, ADSCs also induced an improvement in the cardiac function associated with an increased vasculature in an acute/reperfusion ischemia model in pig [52]. More basic studies are required to better characterize these cell populations which, due to their differentiation potential and simple and innocuous isolation technique, appears to offer a potential clinically useful source of cells for therapeutic transplantation in the heart.

\section{Resident Cardiac Stem Cells}

The existence of cardiac progenitor cells (CPCs) in the adult heart was first reported by Anversa's group [53]. Cells were shown to be distributed in small clusters in the interstices adjacent to the cardiomyocytes and were isolated and characterized by a Sca- $1{ }^{-} \mathrm{cKit}^{+}$phenotype. These cells possess self-renewing, clonogenic and multipotent abilities with potential to differentiate towards cardiomyocytes, endothelial and smooth muscle cells. Importantly, an increase of the CPC pool in the heart after acute myocardial infarction was reported [54] and an improvement in cardiac function after their transplantation in rat ischemic heart muscle was also demonstrated [53]. Recently, their ability to transverse the vessel barrier to engraft into the ischemic heart after intracoronary injection has also been shown [55]. A population of Sca- $1^{+}$cKit cardiac progenitor cells which, after stimulation in vitro with 5-Azacytidine, express cardiac markers has also been described [56], although no spontaneous beating cells could be detected. Importantly, when these cells were intravenously transplanted in previously infarcted and reperfused mice, they could home to the injured heart and differentiate towards cardiomyocytes, $50 \%$ of the differentiated cells being consequence of fusion events [56]. An independent laboratory in Japan was also able to isolate this $\mathrm{Sca}^{+}$population and to differentiate it in vitro towards cardiac cells (surprisingly with oxytocin but not with 5 -azacytidine) and also in vivo, finding $\mathrm{Sca}^{+}$derived endothelial and smooth muscle cells $[57,58]$. Furthermore, a Sca- $1^{+} \mathrm{cKit}^{\mathrm{LOW}}$ cardiac side population defined by the expression of the transport protein Abcg-2, could be differentiated towards cardiomyocytes upon co-culture with rat cardiomyocytes $[59,60]$. Other studies have shown the ability of some cells derived from the murine and human heart to form clusters in vitro when cultured in suspension (named "cardiospheres") [61]. These clusters contain clonally derived cells which organize in a core composed by proliferating c-kit-positive cells and a surrounding layer of spontaneously differentiated cells that express markers characteristic of cardiac, endothelial and mesenchymal cells. Moreover, their transplantation into immunosuppressed infarcted mice improved their cardiac function. Also, proliferation and differentiation of these cells has been reported [62]. Finally, another population of cardiac stem cells has been recently described in rodent and human embryo, newborn and adult right atrium hearts which is characterized by the expression of the LIM-homeodomain transcription factor islet-1 [63]. Their self-renewal and CM differentiation potential has been demonstrated; unlike the other cell populations, these cells do not express cKit or Sca1 receptors. It will be interesting to know whether such a population can be stimulated in the adult heart and what role they can play in the ischemic heart.

Although many studies have focused on the potential of $\mathrm{SC}$ to differentiate into $\mathrm{CMs}$, in order to regenerate the heart tissue, it is equally important to restore the vascular net, 
which will supply the new repopulated tissue with oxygen and nutrients. Importantly, most of the SC previously described (ESCs, SVF and several populations of the BM like the EPCs (Endothelial progenitor cells) also possess the capacity to differentiate into vascular structures.

\section{Skeletal Myoblasts and Satellite Cells}

Although some initial studies suggested that skeletal myoblasts could differentiate towards CMs, their lack of cardiac differentiation potential has been clearly demonstrated. Recently, however, the existence in the skeletal muscle (Sk) of a non-satellite cell population (termed SPOC cells) has been shown, which can differentiate to spontaneously beating cells with cardiac features [64]. Furthermore, another population, which unlike SPOC cells, is phenotypically characterized by the expression of the CD34 marker, has also been identified. Importantly, when the Sk-CD34+ cells were transplanted in the ischemic heart, they induced an improvement in the function [65]. It would be interesting to determine their putative presence in the human skeletal muscle, which has not been described yet. On the other hand, referring to the skeletal myoblasts, despite their lack of cardiac differentiation potential, many studies have been performed in both small and large animals models of MI, showing also an improvement in cardiac function after their transplantation (Reviewed in [66] and [67]). These beneficial effects could be due, at least partially, to a cell paracrine effect, by secretion of factors that can induce the activation of the angiogenesis processes and modulation of the composition of the extracellular matrix. Besides, skeletal myoblasts present high resistance to hypoxia, which give them an advantage over other types of cells which, when transplanted, quickly disappear due to the low oxygen environment. Moreover, the fact that myoblasts are progenitor cells already committed to muscle differentiation with low proliferation rate avoids the tumorigeneic risk that other cells may have. On the other hand, the main limitation of skeletal myoblasts is their inability to electromechanically couple with the surrounding CMs, which it has been argued, could increase the risk of arrhythmias.

\section{Conclusions from the In Vivo Experimental Results}

From all the extensive in vivo data published until now, there are some conclusions and important points that need to be discussed: (1) the low levels of cell engraftment that have been found in the vast majority of the animal experiments performed; (2) the low degree of cell differentiation in vivo and (3) the near lack of correlation between the type of cells transplanted and the functional effect observed.

Cell retention and survival are one of the main technical limitations that stem cell therapy presents nowadays. In the cardiac ischemic tissue, the hypoxic environment together with the inflammation - a process typical of the MI acute stage also provoked by the needle injection during the cell transplantation - significantly diminish the number of engrafted cells which in many cases end up disappearing a few weeks after the transplant. However, despite their limited engraftment, their positive effect in the sick heart has been demonstrated in many studies. Initially, this benefit was attributed to the differentiation potential of the stem cells to cardiac or vascular cell types, but it is clear now that the per- centage of cells that truly differentiate is very low and cannot be fully responsible for the positive effect. Besides, several cell types with very different tissue-origin and differentiation potential have been shown to induce similar benefits. Therefore, it has been hypothesized that a paracrine effect might be, at least partially, the cause of this effect. Cytokines secreted by the transplanted cells could promote angiogenesis, cell proliferation and survival, or extracellular matrix composition changes and might even attract/activate endothelial or cardiac progenitor cells present in the organism (Fig. 1). This hypothesis has been proven by injection of conditioned media recovered from cultured SC, which can also produce some benefit in the injected hearts $[68,69]$. On the other hand, direct treatment with single specific cytokines has also been tested; however, the improvement induced has been significantly lower than with the transplanted cells, probably due to the instability of the cytokine and also because the paracrine cell effect must be consequence of a combination of several factors rather than only one. On these grounds, several bio-engineering approaches have been proposed and tested in order to improve the degree of cell engraftment and survival. Transplantation of stem cells embedded in matrigel or collagen matrixes have been shown to improve the level of engraftment and hence, the cardiac function [70]. Synthetic membranes where cells can be grown in monolayer and be applied as a patch, have also been found to produce significant benefit [71] and more sophisticated techniques, such as 3D scaffolds where cells can integrate, are also being tested [72]. Finally, several experiments have shown a greater positive effect when genetically modified cells expressing some anti-apoptotic factors like Akt or $\mathrm{Bcl} 2$ are transplanted $[69,73]$. Thus, the combination of stem cell therapy with other scientific fields like the bio-engineering and gene therapy could greatly improve the regenerative potential of these cells.

\section{Clinical Trials and Therapeutic Perspectives}

Although more basic studies are needed in order to understand "SC behavior" and also the mechanisms involved in cardiac repair, a number of early phase clinical as well as randomized trials have been performed. Based on the encouraging experimental results and their putative feasibility and safety, skeletal myoblasts and bone marrow derived SC (Hematopoietic SC (HSC) and Mesenchymal SC (MSC)) have been tested. Also, their autologous application which avoids the need for immune-suppression has been an important factor in their choice. More recently, ADSCs have been introduced in the clinical arena.

\section{Clinical Trials Using Skeletal Myoblasts}

The first clinical trial with skeletal myoblasts was started in 2000 on a series of 10 patients with severe ischemic heart failure $(\mathrm{LVEF} \leq 35 \%)$ [74,75] (See Table 1). This group showed an increase in the LVEF during the first year $(24.3 \%$ $\pm 4 \%$ to $31 \% \pm 4.1 \% ; p=0.001$ ) which remained stable in time over 6 years of follow-up [76]. However, tachycardia episodes were detected in 5 of these patients, requiring the implantation of a defibrillator. Even with this, 3 of the patients still suffered arrhythmic storms, which aroused some concerns about the safety of myoblast transplantation. Regarding this issue, in vitro studies showed that neonatal car- 


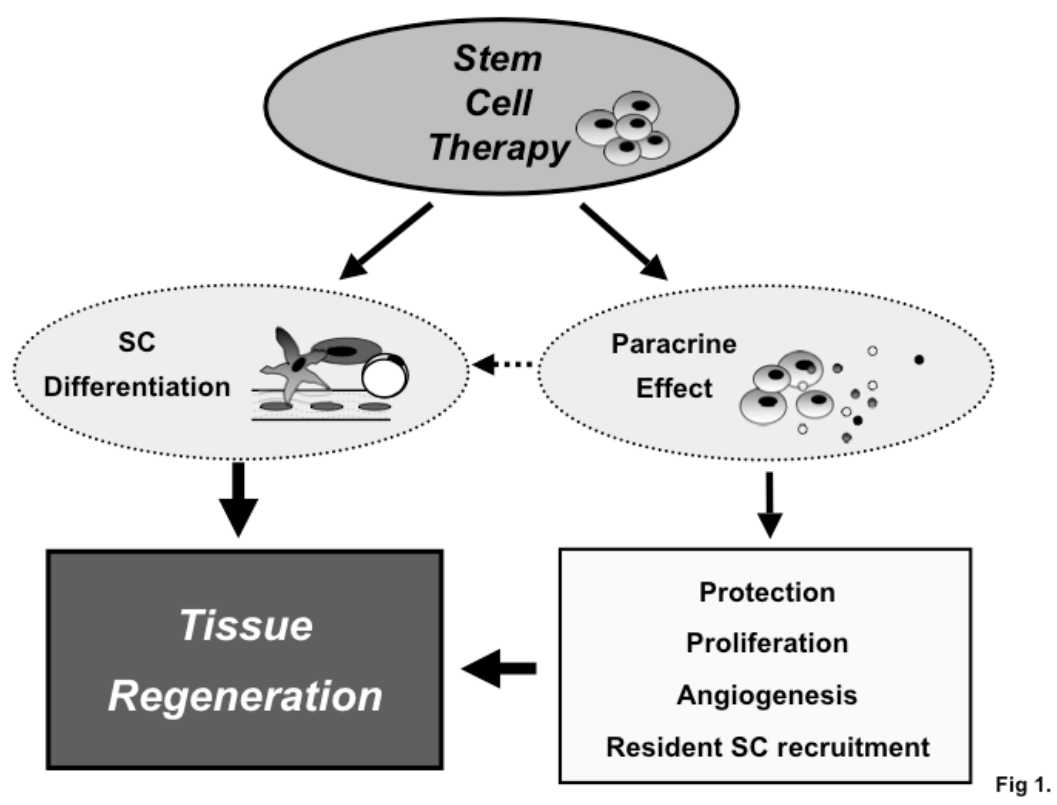

Fig. (1). therapeutic potential: Mechanisms. SC transplantation could induce repair of sick tissue (i) by differentiating itself into the required tissue cell type or (ii) by secretion of cytokines responsible to trigger several mechanisms involved in anti-apoptotic signaling, cell proliferation, angiogeneic processes or recruitment of resident stem cells able to reconstitute the damaged tissue. To better understand the key factors involved in such processes would greatly help to improve the beneficial effect of the transplanted cells.

diomyocytes that were co-cultured with skeletal myoblasts suffered a decrease in the conduction velocity together with arrhythmic contractions [77]. Interestingly, this effect was cell-dose dependent and was detected as long as co-cultures contained more than $20 \%$ of myoblasts but never when the percentage was lower than $5 \%$. Also, in vivo experiments in rats showed the same cell-dose dependency [78]. In patients, although some cases of arrhythmias have been reported, overall, an improvement in the cardiac function together with an increase in the viability and perfusion has been found in most of the clinical trials published so far [79] [76] [80-85]. Some studies like that published by Gavira et al. have been successful with no cardiac arrhythmia reported after one-year follow-up [80]. In this study, cells were cultured in autologous serum instead of bovine serum, which might be associated with lower inflammation. Echocardiography results showed an increase in the ejection fraction from $35.5 \% \pm 2.3 \%$ to $55.1 \% \pm 8.2 \%(\mathrm{p}<0.01)$ together with an improvement in the regional wall contractility (wall motion index from $3.02 \pm 0.17$ to $1.36 \pm 0.14(\mathrm{p}<0.0001)$. PET (positron emission tomography) analysis also detected an increase in viabilty and perfusion levels. Importantly, other studies, tested a wide range of cell doses, from $4 \times 10^{5}$ to $5 \mathrm{x}$ $10^{7}$ [82] or from 1-300 $\times 10^{6}$ cell-dose [81] and although a few cases of arrhythmia were reported, overall, an improvement in the cardiac function together with an increase in the viability and perfusion was determined. The study published by Siminiak et al including 10 patients reported an increase from $35.2 \%$ to $42.0 \%$ in LVEF 4 months after transplant which was maintained during the first year of follow-up. Dib et al (30 patients) showed an increase in the ejection fraction of $7 \%$ (from $28 \%$ to $35 \% ; \mathrm{p}<0.02$ ) during the first year and $8 \%$ after the second year $(\mathrm{p}<0.01)$ together with an improvement in tissue viability. Tachycardia episodes were detected in 3 of the patients. Interestingly, cells were deliv- ered percutaneously, so the feasibility and safety of this route of transplantation were confirmed [86]. A second study was also performed by the group led by Serruys [79] proving also the safety of the method and documenting an increase in the global ejection fraction. Although all these data are quite suggestive, the small number of patients included in these studies as well as the lack of placebo groups make it impossible to draw any definitive conclusion regarding the beneficial effect of this approach. Very importantly, a randomized, double-blind, placebo-controlled dose-ranging trial (MAGIC) has recently been finished including 92 patients from different hospitals [87]. The study was performed in patients with a LVEF between 15 and $35 \%$, a history of acute MI with residual akinesia and clinical indication for CABG (coronary artery bypass graft). Importantly, no significant differences in survival and first ventricular arrhythmia were detected among the three groups at 1 and 6 months. Furthermore, two doses of cells $\left(400 \times 10^{6}\right.$ and $\left.800 \times 10^{6}\right)$ were tested. It was demonstrated that administration of the high cell dose significantly reduced the end-systolic and enddiastolic volumes which translated into an increase of $3 \%$ in the LVEF compared with the placebo group $(\mathrm{p}=0.04)$. Despite some limitations in this trial like the low number of patients, the lack of long term follow-up and the functional quantification by echocardiography rather than magnetic resonance imaging (MRI), this study has helped to clarify the safety of skeletal myoblast treatment and suggest the relative efficiency of the treatment, opening new perspectives for treatment of MI provided that phase III trials confirm the results.

\section{Bone Marrow Derived-Sc Clinical Trials}

Bone marrow has been the most common source of SC tested in human clinical trials (See Table 2). The first trials performed determined the safety and feasibility of SC trans- 
Table 1. Most relevant SkM transplantation Clinical Trials in CMI

\begin{tabular}{|c|c|c|c|c|c|c|c|c|}
\hline Study (Year) & $\begin{array}{c}\text { Cell } \\
\text { Type }\end{array}$ & $\begin{array}{c}\text { Number of } \\
\text { Patients } \\
\text { (Treated/co) }\end{array}$ & $\begin{array}{c}\text { Cell-Dose } \\
(\% \text { cd56+ Cells }) \\
\left(\begin{array}{cc}\left.x_{10}\right) \\
\end{array}\right.\end{array}$ & $\begin{array}{l}\text { Delivery } \\
\text { Time/ } \\
\text { Route }\end{array}$ & $\begin{array}{l}\text { Follow-up } \\
\text { Time } \\
\text { (Months) }\end{array}$ & $\begin{array}{c}\text { \%Lvef Increase } \\
\text { (Basal vs. Treated) } \\
\text { (p in Treated Group) }\end{array}$ & $\begin{array}{l}\text { Lvef Imag- } \\
\text { ing Asses- } \\
\text { ment }\end{array}$ & $\begin{array}{l}\text { Other Func- } \\
\text { tional Out- } \\
\text { comes }\end{array}$ \\
\hline \multicolumn{9}{|c|}{ Non-Randomized Controlled Trials } \\
\hline $\begin{array}{l}\text { Menasche et al. } \\
\quad \text { (75) } 2003 \\
\text { Hagege et al. } \\
\text { (76) } 2006\end{array}$ & SkM & $10 / 0$ & $\begin{array}{c}780-1060 \\
(86)\end{array}$ & $\begin{array}{l}3-228 \mathrm{~m} / \\
\text { TEp w/o } \\
\text { CABG }\end{array}$ & $\begin{array}{c}10.9 \\
52\end{array}$ & $\begin{array}{l}8(*)(10.9 \mathrm{~m}) \\
4 \text { (NS) }(52 \mathrm{~m})\end{array}$ & Echo & $\begin{array}{c}\uparrow \text { Regional } \\
\text { wall motion } \\
\text { (at } 10.9 \mathrm{~m} \text { ); } \\
\uparrow \text { Global } \\
\text { LVEF (at } \\
10.9 \mathrm{~m}) .\end{array}$ \\
\hline $\begin{array}{l}\text { Smits et al. } \\
(\mathbf{8 5}) 2003\end{array}$ & SkM & $5 / 0$ & $\begin{array}{c}90-310 \\
(25-85 \mathrm{D}+)\end{array}$ & $\begin{array}{l}\text { 24-132m/ } \\
\text { TEc }\end{array}$ & 3,6 & $\begin{array}{c}5(* *)(3 \mathrm{~m}) ; 9(\mathrm{NS}) \\
(6 \mathrm{~m})\end{array}$ & $\begin{array}{l}\text { LV angi- } \\
\text { ography, } \\
\text { Echo, MRI }\end{array}$ & $\begin{array}{c}\uparrow \text { Regional } \\
\text { wall motion; } \\
\uparrow \text { Global } \\
\text { LVEF. }\end{array}$ \\
\hline $\begin{array}{l}\text { Ince et al. (84) } \\
2004\end{array}$ & SkM & $6 / 6$ & $60-360$ & $\begin{array}{c}\text { NP } \\
\text { TEc } \\
(\mathrm{EMM})\end{array}$ & 12 & $\begin{array}{c}8(*) \\
\text { Co: }-3\end{array}$ & Echo & $\begin{array}{l}\uparrow \text { Global } \\
\text { LVEF. }\end{array}$ \\
\hline $\begin{array}{l}\text { Gavira et al. } \\
\text { (80) } 2006\end{array}$ & SkM & $12 / 14$ & $\begin{array}{c}190 \pm 120 \\
(65.6)\end{array}$ & $\begin{array}{c}\text { 3-168m } \\
\text { TEp + } \\
\text { CABG }\end{array}$ & 3,12 & $\begin{array}{c}8(* *)(3 \mathrm{~m}), 9(* *) \\
(12 \mathrm{~m}) \\
\text { Co: } 3(\mathrm{NS})(12 \mathrm{~m})\end{array}$ & Echo & $\begin{array}{c}\uparrow \text { Regional } \\
\text { wall motion; } \\
\uparrow \text { Global } \\
\text { LVEF; } \uparrow \text { Tis- } \\
\text { sue Viability; } \\
\uparrow \text { Perfusion. }\end{array}$ \\
\hline $\begin{array}{l}\text { Siminiak et al. } \\
\quad \text { (82) } 2004\end{array}$ & SkM & $10 / 0$ & $\begin{array}{c}0.4-50 \\
(65.4 \mathrm{D}+)\end{array}$ & $\begin{array}{l}4-108 \mathrm{~m} / \\
\text { TEp w/o } \\
\text { CABG }\end{array}$ & 4,12 & $\begin{array}{c}7(*)(4 \mathrm{~m}), 7\left(^{*}\right) \\
(12 \mathrm{~m})\end{array}$ & Echo & $\begin{array}{c}\uparrow \text { Regional } \\
\text { wall motion; } \\
\uparrow \text { Global } \\
\text { LVEF. }\end{array}$ \\
\hline $\begin{array}{l}\text { Chachques et } \\
\text { al. (83) } 2004\end{array}$ & SkM & $20 / 0$ & $\begin{array}{c}300 \pm 20 \\
(78 \pm 5 \mathrm{D}+)\end{array}$ & $\begin{array}{c}\mathrm{NP} / \\
\text { TEp w/o } \\
\text { CABG }\end{array}$ & 9,19 & $24(*)$ & $\begin{array}{l}\text { Echo, } \\
\text { SPECT }\end{array}$ & $\begin{array}{c}\uparrow \text { Regional } \\
\text { wall motion; } \\
\uparrow \text { Global } \\
\text { LVEF; } \uparrow \text { Tis- } \\
\text { sue Viability. }\end{array}$ \\
\hline $\begin{array}{l}\text { Dib et al. (81) } \\
2005\end{array}$ & SkM & $30 / 0$ & $\begin{array}{l}2.2-300 \\
(42-98)\end{array}$ & $\begin{array}{l}\text { NP/ } \\
\text { TEp w/o } \\
\text { CABG or } \\
\text { LVAD }\end{array}$ & 12,24 & $\begin{array}{c}7(*)(12 \mathrm{~m}), 8(*) \\
(24 \mathrm{~m})\end{array}$ & $\begin{array}{l}\text { Echo, } \\
\text { SPECT, } \\
\text { MRI }\end{array}$ & $\begin{array}{c}\uparrow \text { Regional } \\
\text { wall motion; } \\
\uparrow \text { Global } \\
\text { LVEF; } \uparrow \text { Tis- } \\
\text { sue Viability; } \\
\downarrow \text { ESV; } \downarrow \text { EDV. }\end{array}$ \\
\hline $\begin{array}{l}\text { Siminiak et al. } \\
\quad \text { (86) } 2005\end{array}$ & SkM & $9 / 0$ & $\begin{array}{c}17-106 \\
(65)\end{array}$ & $\begin{array}{l}5-96 \mathrm{~m} / \\
\mathrm{TC}\end{array}$ & 2.5 & $\begin{array}{c}3-8 \text { in } 6 / 9 \text { patients } \\
\text { (Not statistically ana- } \\
\text { lyzed) }\end{array}$ & Echo & $\begin{array}{l}\text { Symptoms } \\
\text { improved. }\end{array}$ \\
\hline $\begin{array}{l}\text { Biagini et al. } \\
\text { (79) } 2006\end{array}$ & SkM & $10 / 0$ & $\begin{array}{c}217 \pm 111 \\
(64 \pm 27 \mathrm{D}+)\end{array}$ & $\begin{array}{l}28-140 \mathrm{~m} / \\
\text { TEc }\end{array}$ & $1,3,6,12$ & $6(* *)(12 \mathrm{~m})$ & Echo, TDI & $\begin{array}{c}\uparrow \text { Regional } \\
\text { wall motion; } \\
\downarrow \mathrm{ESV} ; \approx \mathrm{EDV} \text {. }\end{array}$ \\
\hline \multicolumn{9}{|c|}{ Randomized Controlled Trials } \\
\hline $\begin{array}{c}\text { MAGIC/ } \\
\text { Menasche et al. } \\
\text { (87) } 2008\end{array}$ & SkM & $\begin{array}{l}30 \mathrm{HD} / 34 \\
33 \mathrm{LD} / 34\end{array}$ & $\begin{array}{l}800 \text { (HD) } 400 \\
\text { (LD) } \\
\text { (89) }\end{array}$ & $\begin{array}{c}\mathrm{NP} \\
\mathrm{TEp}+ \\
\mathrm{CABG}\end{array}$ & 6 & $0.8(\mathrm{NS})(\mathrm{HD})$ & Echo & $\begin{array}{c}\approx \text { Global } \\
\text { LVEF; } \downarrow \text { ESV } \\
\text { (HD). }\end{array}$ \\
\hline
\end{tabular}

plantation, showing also a functional improvement [88-93]. However, these trials included a limited number of patients, and this, along with the lack of randomization and doubleblinded performance, meant that the reliability of the results could not be tested. Moreover, the significant heterogeneity in the type of cell populations used (BM-Mononuclear cells (BM-MNC), sorted BM fractions, in vitro cultured cells (MSCs) or G-CSF mobilized cells), the delivery route (endocardial catheter-based or epicardial surgical-based or percutaneous catheter-based intracoronary injec tion) and the tim- ing of transplantation all limited the conclusions of these studies.

The first randomized trial, the BOOST I trial (BOne marrow transfer to enhance ST-elevation infarct regeneration) was performed in 60 patients with acute MI. Thirty of the patients received $2.5 \pm 0.9 \times 10^{9}$ unfractionated BM-MNCs by intracoronary delivery $\sim 6$ days after occlusion. Although a control group that did not receive cells was included, no bone marrow aspiration or sham infusion was performed in 
Table 2. Most Relevant BM Transplantation Clinical Trials in AMI

\begin{tabular}{|c|c|c|c|c|c|c|c|c|c|}
\hline $\begin{array}{l}\text { Study } \\
\text { (Year) }\end{array}$ & $\begin{array}{c}\text { Cell } \\
\text { Type }\end{array}$ & $\begin{array}{c}\text { Number Of } \\
\text { Patients } \\
\text { (Treated/co) }\end{array}$ & $\begin{array}{c}\text { Cell-Dose } \\
(\% \text { cd34+ } \\
\text { Cells }) \\
\left(\begin{array}{ll}\left.\mathbf{x} 10^{6}\right)\end{array}\right.\end{array}$ & Sham? & $\begin{array}{l}\text { Delivery } \\
\text { Time/ } \\
\text { Route }\end{array}$ & $\begin{array}{l}\text { Follow- } \\
\text { up Time } \\
\text { (Months) }\end{array}$ & $\begin{array}{c}\text { \%Lvef Increase } \\
\text { (Basal vs. Treated) } \\
\text { (p in Treated } \\
\text { Group) }\end{array}$ & $\begin{array}{l}\text { Lvef Im- } \\
\text { aging } \\
\text { Assesment }\end{array}$ & $\begin{array}{l}\text { Other Func- } \\
\text { tional Out- } \\
\text { comes }\end{array}$ \\
\hline \multicolumn{10}{|l|}{$\begin{array}{c}\text { Non- } \\
\text { Random- } \\
\text { ized } \\
\text { Controlled } \\
\text { Trials }\end{array}$} \\
\hline $\begin{array}{l}\text { Strauer et } \\
\text { al. (93) } \\
2002\end{array}$ & $\mathrm{BMC}$ & $20(10 / 10)$ & $9-28(0.39)$ & No & $5-9 d+/ I C$ & 3 & 4 vs 5 ; (NS) & $\begin{array}{l}\text { LV angi- } \\
\text { ography }\end{array}$ & $\begin{array}{c}\downarrow \text { ESV; } \\
\approx \text { EDV; } \\
\uparrow \text { Perfusion; } \\
\uparrow \text { Regional } \\
\text { wall motion; } \\
\downarrow \text { Infarct } \\
\text { Size. }\end{array}$ \\
\hline $\begin{array}{l}\text { Fernandez- } \\
\text { Aviles et al. } \\
\text { (89) } 2004\end{array}$ & $\mathrm{BMC}$ & $33(20 / 13)$ & $37-119$ & No & $8-19 \mathrm{~d}+/ \mathrm{IC}$ & 6 & $5.8 ;(* *)$ & $\begin{array}{l}\text { Cardiac } \\
\text { MRI }\end{array}$ & $\begin{array}{c}\downarrow E S V ; \\
\approx E D V ; \\
\uparrow \text { Thickness } \\
\text { of infarct } \\
\text { wall. }\end{array}$ \\
\hline \multicolumn{10}{|l|}{$\begin{array}{l}\text { Random- } \\
\text { ized } \\
\text { Controlled } \\
\text { Trials }\end{array}$} \\
\hline $\begin{array}{l}\text { BOOST I/ } \\
\text { Wollert et } \\
\text { al. (96) } \\
2004 \\
\text { Schaefer } \\
\text { (95) } 2006\end{array}$ & $\mathrm{BMC}$ & $60(30 / 30)$ & $2460(9.5)$ & No & $6 \mathrm{~d}+/ \mathrm{IC}$ & 6,18 & $\begin{array}{c}0.7 \text { vs } 6.7 ;(* *)(6 \mathrm{~m}) \\
3.1 \text { vs } 5.9 ;(\mathrm{NS}) \\
(18 \mathrm{~m})\end{array}$ & MRI & $\begin{array}{l}\downarrow \text { Infarct } \\
\text { Size. }\end{array}$ \\
\hline $\begin{array}{l}\text { Chen et al. } \\
\text { (97) } 2004\end{array}$ & MSC & $69(34 / 35)$ & $4800-6000$ & Yes & $18 \mathrm{~d}+/ \mathrm{IC}$ & 6 & 6 vs $8 ;(*)$ & $\begin{array}{l}\text { LV angi- } \\
\text { ography }\end{array}$ & $\begin{array}{c}\quad \downarrow \text { ESV; } \\
\uparrow \text { Perfusion; } \\
\uparrow \text { Regional } \\
\text { wall motion. }\end{array}$ \\
\hline $\begin{array}{c}\text { Jannsens et } \\
\text { al. (99) } \\
2006\end{array}$ & $\mathrm{BMC}$ & 66 & $304(2.8)$ & Yes & $24 \mathrm{~h}+/ \mathrm{IC}$ & 4 & 2.2 vs $3.3 ;(\mathrm{NS})$ & MRI & $\begin{array}{c}\uparrow \text { Perfusion; } \\
\downarrow \text { Infarct } \\
\text { Size; } \\
\uparrow \text { Tissue } \\
\text { Viability. }\end{array}$ \\
\hline $\begin{array}{l}\text { ASTAMI/ } \\
\text { Lunde } \text { et al. } \\
(\mathbf{1 0 2}) 2006 \text {, } \\
\text { Lunde } \text { et al. } \\
\text { (103) } 2007\end{array}$ & $\mathrm{BMC}$ & $97(47 / 50)$ & $68(0.7)$ & No & $4-8 d+/ I C$ & 6 & 6.7 vs $8 ;$ (NS) & $\begin{array}{l}\text { SPECT, } \\
\text { MRI, Echo }\end{array}$ & $\begin{array}{l}\quad \approx \mathrm{ESV} ; \\
\approx \mathrm{EDV} ; \approx \mathrm{In}- \\
\text { farct Size; } \\
\approx \text { Perfusion. }\end{array}$ \\
\hline
\end{tabular}


Table 2. Contd....

\begin{tabular}{|c|c|c|c|c|c|c|c|c|c|}
\hline $\begin{array}{l}\text { Study } \\
\text { (Year) }\end{array}$ & $\begin{array}{l}\text { Cell } \\
\text { Type }\end{array}$ & $\begin{array}{l}\text { Number Of } \\
\text { Patients } \\
\text { (Treated/co) }\end{array}$ & $\begin{array}{c}\text { Cell-Dose } \\
\text { (\%cd34+ } \\
\text { Cells) } \\
\left(\begin{array}{ll}\text { x 10 } \\
\text { ( })\end{array}\right.\end{array}$ & Sham? & $\begin{array}{c}\text { Delivery } \\
\text { Time/ } \\
\text { Route }\end{array}$ & $\begin{array}{l}\text { Follow- } \\
\text { up Time } \\
\text { (Months) }\end{array}$ & $\begin{array}{c}\text { \%Lvef Increase } \\
\text { (Basal vs. Treated) } \\
\text { (p in Treated } \\
\text { Group) }\end{array}$ & $\begin{array}{l}\text { Lvef Im- } \\
\text { aging } \\
\text { Assesment }\end{array}$ & $\begin{array}{l}\text { Other Func- } \\
\text { tional Out- } \\
\text { comes }\end{array}$ \\
\hline $\begin{array}{l}\text { REPAIR- } \\
\text { AMI/ } \\
\text { Schachinger } \\
\text { et al. (101) } \\
2006 \\
\text { Erbs et al. } \\
\text { (100) } 2007\end{array}$ & BMC & $\begin{array}{c}204 \\
(101 / 103)\end{array}$ & $236(3.6)$ & Yes & $3-6 d+/ I C$ & 4,12 & 3 vs $5.5 ;\left(^{*}\right)$ & $\begin{array}{l}\text { LV angi- } \\
\text { ography, } \\
\text { MRI }\end{array}$ & $\begin{array}{c}\approx \mathrm{ESV} \\
\approx \mathrm{EDV} ; \approx \mathrm{In}- \\
\text { farct Size. }\end{array}$ \\
\hline $\begin{array}{l}\text { Meluzin et } \\
\text { al. (105) } \\
2006 \\
\text { Meluzin et } \\
\text { al (104) } \\
2007\end{array}$ & $\mathrm{BMC}$ & $\begin{array}{c}66 \\
(22 / 22+22)\end{array}$ & $\begin{array}{c}100(\mathrm{HD}) \\
10(\mathrm{LD})\end{array}$ & No & $6-10 \mathrm{~d}+/ \mathrm{IC}$ & $3,6,12$ & $\begin{array}{c}3 \text { vs } 6 ;(\mathrm{NS})(3 \mathrm{~m}) \\
0 \text { vs } 7 ;(*)(6 \mathrm{~m}) \\
(\mathrm{HD}) \\
0 \text { vs } 7 ;\left({ }^{* *}\right)(12 \mathrm{~m}) \\
(\mathrm{HD})\end{array}$ & $\begin{array}{l}\text { SPECT, } \\
\text { Echo }\end{array}$ & $\begin{array}{l}\downarrow \mathrm{ESV} ; \\
\approx \mathrm{EDV} ; \\
\uparrow \text { Perfusion. }\end{array}$ \\
\hline
\end{tabular}

Abbreviations: BMC: Bone Marrow Cells. CPC: Blood derived-Circulating Progenitor Cells. Co: Control group. NP: Not Provided. HD: High cell Dose. IC: Intracoronary. NS: Not Significant. *: P<0.05. **: P<0.01. LV: Left Ventricular. Echo: Echocardiography. MRI: Magnetic Resonance Imaging. SPECT: Single Photon Emission Tomography. ESV: End Systolic Volume. EDV: End Diastolic Volume.

the control group. After 6 months, an improvement in the ejection fraction $(50.0 \%$ to $56.7 \%$ in treated $v s .51 .3 \%$ to $52.0 \%$ in controls) with no significant changes in the LVend-diastolic volumes or reduction of the infarct size, was demonstrated; Follow up of these patients showed that such improvement was transitory and by 18 months there was no statistical differences in the global LV ejection fraction between the control and the treated groups (3.1 percentage points in the control group vs. 5.9 in the treated group) [9496].

Close in time, another similar study performed with MSCs in 69 patients showed an improvement in the global LVEF (from $48 \pm 10$ to $54 \pm 5$ in the control group and from $49 \pm 9$ to $67 \pm 3$ in the treated group; $p=0.01$ ), together with a reduction of the end-systolic and diastolic volumes and an improved contractility index, wall motion and velocity and increased tissue viability. Unfortunately, the functional studies were performed at 6 months and no long-term follow-up was performed [97]. In another clinical trial, CD133 ${ }^{+}$selected BM-MNC were transferred to a series of 14 patients. Global LVEF, regional wall motion and tissue perfusion increased in the treated group after 4 months. However, secondary effects like restenosis or de novo lesions developed in 6 of the 14 patients, provoking some concerns among the scientific community [98]. Importantly, in 2006, the group of Janssen et al. published the results of the first randomized, double-blinded, placebo-controlled trial [99]. In this study, intracoronary transplantation of BM-MNC was performed in 33 patients with AMI, 24h after reperfusion (34 were included as placebo). A reduction of the infarct size and a better recovery of the regional systolic function were detected after 4 months, but no significant functional improvement or a significant improvement of myocardial perfusion and metabolism indexes were detected. During the same year, the results of another two studies performed with a larger number of patients were also published. Contradictory results were obtained; whereas in the REPAIR-AMI trial (Reinfusion of Enriched Progenitor Cells and Infarct Remodeling in Acute Myocardial Infarction), an improvement of the ejection fraction together with a reduction of the infarct size and a restoration of the microvascular function of the infarct- related artery [100] 4 months after transplantation were seen [101], no differences were found in the ASTAMI trial (Autologous Stem Cell Transplantation in Acute Myocardial Infarction) [102] despite an improvement in exercise time and heart rate responses to exercise [103]. In both studies, the method of cell delivery (intracoronary) and the SC source used (BM-MNC) were similar. It is possible, however, that the timing of cell-delivery, the method of cell isolation and/or the degree of severity on the patients condition could vary between these trials, explaining the contradictory results. Also, a slightly smaller number of cells (2-4 times fewer) was injected in the ASTAMI trial. Along similar lines, the last two studies published by Meluzin et al. $[104,105]$ showed that the benefit of BM-MNC transplantation in acute MI can be cell-dose dependent. Three months after transplantation, a significant functional improvement was detected only in the group transplanted with the higher cell-dose $\left(10^{8}\right.$ cells $v s$. the lower cell-dose $10^{7}$ cells $)$ with a $5 \%$ vs. a $3 \%$ LVEF increase ( $<<0.05 v s$. control group).

A very interesting meta-analysis [106] of 10 controlled clinical trials performed with BM-MNC in patients with recent acute MI ( $\leq 14$ days) has recently been published. The statistical results suggest that intracoronary cell therapy following percutaneous coronary intervention for acute MI can provide statistically and clinically relevant benefits for cardiac function and remodeling. Moreover, it has also suggested a dose-response association with such benefits.

Finally, various other trials have been performed with mobilized cells after G-CSF treatment. The first clinical trial performed (Front-Integrated Revascularization and Stem cell Liberation In Evolving Acute Myocardial Infarction: FIRSTLINE-AMI) [107] [108] suggested an improvement of cardiac function, but a placebo-controlled clinical trial (REgenerate VItal Myocardium by Vigorous Activation of bone marrow stem cells: REVIVAL II and STEM cells in Myocardial Infarction: STEMMI) did not confirm such a benefit [109-111]. It could be argued that the late application of the G-CSF in the REVIVAL II study (5 days after reperfusion $v s .90 \mathrm{~min}$ ) could be the cause of the different results in these studies. There is growing evidence that G-CSF could have a 
more cardioprotective than cell-mediated effect [112], and therefore, the time of injection could be a critical factor for its positive effect. However, in the last randomized, doubleblind, placebo-controlled trial performed, the STEMMI trial, G-SCF was applied also at an earlier time-point (12h after reperfusion), with a similar pattern to the FIRSTLINE-AMI trial, although a functional benefit could not be detected. LVEF improved similarly in the control and treated groups measured both by MRI $(8.5 v s .8 .0 ; p=0.9)$ and echocardiography (5.7 vs. 3.7; $p=0.7)$. Importantly, no clinical adverse effects were detected.

In conclusion, performing multicenter randomized trials with long-term follow-up is mandatory in order to demonstrate the efficacy of BM-MNC transplantation and to establish, for the greatest efficacy, the ideal cell type, cell-dose and surgical procedure (delivery route, transplantation timepoint, etc.).

\section{FUTURE STUDIES}

The scientific community and the media have hailed Stem Cell therapy as a therapeutic alternative for conventional medicine based on pharmacologic treatment. The idea of replacing damaged tissues or dysfunctional cells sometimes due to genetic diseases- opened a new perspective on traditional medicine. However, although our basic knowledge about these recently discovered cells is growing, there are many questions and technical limitations that need to be answered or solved in order to better apply these cells as an effective treatment. Both basic research and clinical trials suggest that $\mathrm{SC}$ transplantation has a positive effect in certain patients with myocardial infarction. However, it is still very important to investigate how to augment the stability of the cells once transplanted and also to understand the molecular mechanisms involved in such benefits. Due to the low engraftment and permanence of the transplanted cells in the heart, and the fact that they still resulted in functional improvement, it has been proposed that the factors and cytokines released by the transplanted cells could trigger several mechanisms, such as angiogenesis, proliferation and protection, which could contribute to tissue regeneration. Although other mechanisms cannot be discarded, a better understanding of the paracrine effect, identifying the key molecules and pathways responsible for such improvement, would enormously help to direct the therapy in a more specific and efficient way. Also, the differentiation pathways and molecular mechanisms at the protein, transcriptional and epigenetic levels are being studied intensely, in order to find ways to manipulate the differentiation of these cells towards the required cell type. This last issue is an important subject if we take into account the fact that even if the cells present multior pluri-potent capabilities, once they are transplanted in the sick tissue it is probable that they will not receive the proper signaling for it. One possible alternative to this limitation could be to transplant in vitro pre-differentiated cells.

In summary, we could conclude from all the results reviewed until now that stem cell application in cardiovascular disease presents great potential and that we can be optimistic about its therapeutic potential. None the less, many studies need to be performed in order to understand their origin and behavior and to be able to apply them in routine clinical practice.

\section{ACKNOWLEDGEMENT}

Supported in part by grants from the Ministerio de Sanidad (PI042125, PI050168, PI070474), RETIC RD06/0014 and the "UTE project CIMA"

\section{ABBREVIATIONS LIST}

\begin{tabular}{|c|c|c|}
\hline ADSCs & $=$ & pose Derived Stem Cells \\
\hline ASTAMI & $=$ & $\begin{array}{l}\text { Autologous Stem Cell Transplantation in } \\
\text { cute Myocardial Infarction }\end{array}$ \\
\hline $\mathrm{BM}$ & $=$ & Bone Marrow \\
\hline BM-MNC & $=$ & Bone Marrow Mononuclear Cells \\
\hline BMP4 & $=$ & Bone Morphogenetic protein 4 \\
\hline BOOST & $=$ & $\begin{array}{l}\text { Bone Marrow transfer to enhance ST- } \\
\text { elevation infarct regeneration }\end{array}$ \\
\hline CABG & $=$ & Coronary Artery Bypass Graft \\
\hline $\mathrm{CMs}$ & $=$ & Cardiomyocytes \\
\hline $\mathrm{CPCs}$ & $=$ & Cardiac Progenitor Cells \\
\hline $3 \mathrm{D}$ & $=$ & Three Dimensions \\
\hline EPCs & $=$ & Endothelial Progenitor Cells \\
\hline $\begin{array}{l}\text { FIRST- } \\
\text { INE-AMI }\end{array}$ & $=$ & $\begin{array}{l}\text { Front-Integrated revascularization and } \\
\text { tem ell Liberation In Evolving Acute Myo } \\
\text { cardial nfarction }\end{array}$ \\
\hline G-CSF & $=$ & Granulocyte-Colony Stimulating Factor \\
\hline GFP & $=$ & Green Fluorescent Protein \\
\hline HSC & $=$ & Hematopoietic Stem Cells \\
\hline LVEF & $=$ & Left Ventricular Ejection Fraction \\
\hline MAGIC & $=$ & $\begin{array}{l}\text { Myoblast Autologous Grafting in Ischemic } \\
\text { Cardiomyopathy }\end{array}$ \\
\hline MAPCs & $=$ & Multipotent Adult Progenitor Cells \\
\hline MCP-1 & $=$ & Monocyte Chemoattractant Protein-1 \\
\hline MI & $=$ & Myocardial Infarction \\
\hline MIAMI & $=$ & $\begin{array}{l}\text { Marrow-Isolated Adult Multilineage In- } \\
\text { ducible cells }\end{array}$ \\
\hline MRI & $=$ & Magnetic Resonance Imaging \\
\hline MSC & $=$ & Mesenchymal Stem Cells \\
\hline Oct4 & $=$ & Octamer-4 \\
\hline TNF- $\alpha$ & $=$ & Tumor Necrosis Factor $-\alpha$ \\
\hline PDGF-BB & $=$ & Platelet-derived Growth Factor-BB \\
\hline PET & $=$ & Positron Emission Tomography \\
\hline $\begin{array}{l}\text { REPAIR- } \\
\text { AMI }\end{array}$ & $=$ & $\begin{array}{l}\text { Reinfusion of Enriched Progenitor Cells } \\
\text { and Infarct Remodeling in Acute Myocar- } \\
\text { dial Infarction }\end{array}$ \\
\hline
\end{tabular}

REVIVAL $=$ Regenerate Vital Myocardium by Vigorous Activation of bone marrow stem cells 


$\begin{array}{ll}\text { Sca1 } & =\text { Stem Cell Antigen-1 } \\ \text { Sk } & =\text { Skeletal muscle } \\ \text { SPOC } & =\text { Skeletal Precursors Of Cardiomyocytes } \\ \text { SSEA } & =\text { Stage Specific Embryonic Antigen } \\ \text { STEMMI } & =\text { STEM cells in Myocardial Infarction } \\ \text { SVF } & =\text { Stromal Vascular Fraction } \\ \text { TGF- } \beta 1 & =\text { Transforming Growth Factor }-\beta 1 \\ \text { VEGF } & =\text { Vascular Endothelial Growth Factor } \\ \text { VSEL } & =\text { Very Small Embryonic Like cells }\end{array}$

\section{REFERENCES}

[1] Francis GS, Tang WH. Pathophysiology of congestive heart failure. Rev Cardiovasc Med 2003; 4(Suppl 2): S14-20.

[2] Capi O, Gepstein L. Myocardial regeneration strategies using human embryonic stem cell-derived cardiomyocytes. J Control Release 2006; 116(2): 211-8.

[3] Passier R, Mummery C. Origin and use of embryonic and adult stem cells in differentiation and tissue repair. Cardiovasc Res 2003; 58(2): 324-35.

[4] Wobus AM, Boheler KR. Embryonic stem cells: prospects for developmental biology and cell therapy. Physiol Rev 2005; 85(2): 635-78.

[5] Kehat I, Kenyagin-Karsenti D, Snir M, et al. Human embryonic stem cells can differentiate into myocytes with structural and functional properties of cardiomyocytes. J Clin Invest 2001; 108(3): 407-14.

[6] Mummery C, Ward-Van Oostwaard D, Doevendans P, et al. Differentiation of human embryonic stem cells to cardiomyocytes: role of coculture with visceral endoderm-like cells. Circulation 2003; 107(21): 2733-40.

[7] Dolnikov K, Shilkrut M, Zeevi-Levin N, et al. Functional properties of human embryonic stem cell-derived cardiomyocytes. Ann N Y Acad Sci 2005; 1047: 66-75.

[8] Kehat I, Khimovich L, Caspi O, et al. Electromechanical integration of cardiomyocytes derived from human embryonic stem cells. Nat Biotechnol 2004; 22(10): 1282-9.

[9] Laflamme MA, Gold J, Xu C, et al. Formation of human myocardium in the rat heart from human embryonic stem cells. Am J Pathol 2005; 167(3): 663-71.

[10] Behfar A, Zingman LV, Hodgson DM, et al. Stem cell differentiation requires a paracrine pathway in the heart. Faseb J 2002; 16(12): 1558-66.

[11] Nussbaum J, Minami E, Laflamme MA, et al. Transplantation of undifferentiated murine embryonic stem cells in the heart: teratoma formation and immune response. Faseb J 2007; 21(7): 1345-57.

[12] Wei H, Juhasz O, Li J, Tarasova YS, Boehler KR. Embryonic stem cells and cardiomyocyte differentiation: phenotypic and molecular analyses. J Cell Mol Med 2005; 9(4): 804-17.

[13] Mcdevitt TC, Laflamme MA, Murry CE. Proliferation of cardiomyocytes derived from human embryonic stem cells is mediated via the IGF/PI 3-kinase/Akt signaling pathway. J Mol Cell Cardiol 2005; 39(6): 865-73.

[14] Xu C, Police S, Rao N, Carpenter MK. Characterization and enrichment of cardiomyocytes derived from human embryonic stem cells. Circ Res 2002; 91(6): 501-8.

[15] Huber I, Itzhaki I, Caspi O, et al. Identification and selection of cardiomyocytes during human embryonic stem cell differentiation. Faseb J 2007; 21(10): 2551-63.

[16] Kolossov E, Bostani T, Roell W, et al. Engraftment of engineered ES cell-derived cardiomyocytes but not BM cells restores contractile function to the infarcted myocardium. J Exp Med 2006; 203(10): 2315-27.

[17] Schroeder M, Niebruegge S, Werner A, et al. Differentiation and lineage selection of mouse embryonic stem cells in a stirred bench scale bioreactor with automated process control. Biotechnol Bioeng 2005; 92(7): 920-33.
[18] Zandstra PW, Bauwens C, Yin T, et al. Scalable production of embryonic stem cell-derived cardiomyocytes. Tissue Eng 2003; 9(4): 767-78.

[19] Behfar A, Perez-Terzic C, Faustino RS, et al. Cardiopoietic programming of embryonic stem cells for tumor-free heart repair. J Exp Med 2007; 204(2): 405-20.

[20] Laflamme MA, Chen KY, Naumova AV, et al. Cardiomyocytes derived from human embryonic stem cells in pro-survival factors enhance function of infarcted rat hearts. Nat Biotechnol 2007; 25(9): 1015-24.

[21] Van Laake LW, Passier R, Doevendans PA, Mummery CL. Human embryonic stem cell-derived cardiomyocytes and cardiac repair in rodents. Circ Res 2008; 102(9): 1008-10.

[22] Makino S, Fukuda K, Miyoshi S, et al. Cardiomyocytes can be generated from marrow stromal cells in vitro. J Clin Invest 1999; 103(5): 697-705.

[23] Hocht-Zeisberg E, Kahnert H, Guan K, et al. Cellular repopulation of myocardial infarction in patients with sex-mismatched heart transplantation. Eur Heart J 2004; 25(9): 749-58.

[24] Deb A, Wang S, Skelding KA, et al. Bone marrow-derived cardiomyocytes are present in adult human heart: A study of gendermismatched bone marrow transplantation patients. Circulation 2003; 107(9): 1247-49.

[25] Laflamme MA, Myerson D, Saffitz JE, Murry CE. Evidence for cardiomyocyte repopulation by extracardiac progenitors in transplanted human hearts. Circ Res 2002; 90(6): 634-40.

[26] Muller P, Pffeiffer P, Koglin J, et al. Cardiomyocytes of noncardiac origin in myocardial biopsies of human transplanted hearts. Circulation 2002; 106(1): 31-35.

[27] Nygren JM, Jovinge S, Breitbach M, et al. Bone marrow-derived hematopoietic cells generate cardiomyocytes at a low frequency through cell fusion, but not transdifferentiation. Nat Med 2004; 10(5): 494-501.

[28] Alavrez-Dolado M, Pardal R, Garcia-Verdugo JM, et al. Fusion of bone-marrow-derived cells with Purkinje neurons, cardiomyocytes and hepatocytes. Nature 2003; 425(6961): 968-73.

[29] Orlic D, Kajstura J, Chimenti S, et al. Bone marrow cells regenerate infarcted myocardium. Nature 2001; 410(6829): 701-5.

[30] Murry CE, Soonpaa MH, Reinecke H, et al. Haematopoietic stem cells do not transdifferentiate into cardiac myocytes in myocardial infarcts. Nature 2004; 428(6983): 664-8.

[31] Balsam LB, Wagers AJ, Christensen JL, et al. Haematopoietic stem cells adopt mature haematopoietic fates in ischaemic myocardium. Nature 2004; 428(6983): 668-73.

[32] Fazel S, Cimini M, Chen L, et al. Cardioprotective c-kit+ cells are from the bone marrow and regulate the myocardial balance of angiogenic cytokines. J Clin Invest 2006; 116(7): 1865-77.

[33] Jiang Y, Jahagirdar BN, Reinhardt RL, et al. Pluripotency of mesenchymal stem cells derived from adult marrow. Nature 2002; 418(6893): 41-49.

[34] Reyes M, Lund T, Lenvik T, et al. Purification and ex vivo expansion of postnatal human marrow mesodermal progenitor cells. Blood 2001; 98(9): 2615-25.

[35] D'ippolito G, Diabira S, Howard GA, et al. Marrow-isolated adult multilineage inducible (MIAMI) cells, a unique population of postnatal young and old human cells with extensive expansion and differentiation potential. J Cell Sci 2004; 117(Pt 14): 2971-81.

[36] Kucia M, Reca R, Campbell FR, et al. A population of very small embryonic-like (VSEL) CXCR4(+)SSEA-1(+)Oct-4+ stem cells identified in adult bone marrow. Leukemia (2006) 20(5): 857-69.

[37] Anjos-Afonso F, Bonnet D. Non-hematopoietic/endothelial SSEA1 pos cells defines the most primitive progenitors in the adult murine bone marrow mesenchymal compartment. Blood 2007; 109(3): 1298-1306.

[38] Nayernia K, Lee JH, Drusenheimer N, et al. Derivation of male germ cells from bone marrow stem cells. Lab Invest 2006; 86(7):654-63.

[39] Yoon YS, Wecker A, Heyd L, et al. Clonally expanded novel multipotent stem cells from human bone marrow regenerate myocardium after myocardial infarction. J Clin Invest 2005; 115(2): 32638.

[40] Kucia M, Dawn B, Hunt G, et al. Cells expressing early cardiac markers reside in the bone marrow and are mobilized into the pe- 
ripheral blood after myocardial infarction. Circ Res 2004; 95(12): 1191-99.

[41] Pelacho B, Nakamura Y, Zhang J, et al. Multipotent Adult Progenitor Cell transplantation increases vascularity and improves left ventricular function after myocardial infarction. Journal of Tissue Engineering and Regenerative Medicine 2007; 1(1): 51-59.

[42] Agbulut O, Vandervelde S, Al Attar N, et al. Comparison of human skeletal myoblasts and bone marrow-derived CD133+ progenitors for the repair of infarcted myocardium. J Am Coll Cardiol 2004; 44(2): 458-63.

[43] Aranguren XL, Luttun A, Clavel C, et al. In vitro and in vivo arterial differentiation of human multipotent adult progenitor cells. Blood 2007; 109(6): 2634-42.

[44] Ross JJ, Hong Z, Willenbring B, et al. Cytokine-induced differentiation of multipotent adult progenitor cells into functional smooth muscle cells. J Clin Invest 2006; 116(12): 3139-49.

[45] Cousin B, Andre M, Arnaud E, Penicaud L, Casteilla L. Reconstitution of lethally irradiated mice by cells isolated from adipose tissue. Biochem Biophys Res Commun 2003; 301(4): 1016-22.

[46] Planat-Benard V, Silvestre JS, Cousin B, et al. Plasticity of human adipose lineage cells toward endothelial cells: physiological and therapeutic perspectives. Circulation 2004; 109(5): 656-63.

[47] Planta-Bernard V, Menard C, Andre M, et al. Spontaneous cardiomyocyte differentiation from adipose tissue stroma cells. Circ Res 2004; 94(2): 223-29.

[48] Cao Y, Sun Z, Liao L, et al. Human adipose tissue-derived stem cells differentiate into endothelial cells in vitro and improve postnatal neovascularization in vivo. Biochem Biophys Res Commun 2005; 332(2): 370-79.

[49] Rehman J, Traktuev D, Li J, et al. Secretion of angiogenic and antiapoptotic factors by human adipose stromal cells. Circulation 2004; 109(10): 1292-98.

[50] Strem BM, Zhu M, Alfonso Z, et al. Expression of cardiomyocytic markers on adipose tissue-derived cells in a murine model of acute myocardial injury. Cytotherapy 2005; 7(3): 282-91.

[51] Yamada Y, Wang XD, Yokoyama S, Fukuda N, Takakura N. Cardiac progenitor cells in brown adipose tissue repaired damaged myocardium. Biochem Biophys Res Commun 2006; 342(2): 66270 .

[52] Valina C, Pinkernell K, Song $\mathrm{YH}$, et al. Intracoronary administration of autologous adipose tissue-derived stem cells improves left ventricular function, perfusion, and remodelling after acute myocardial infarction. Eur Heart J 2007; 28(21): 2667-77.

[53] Beltrami AP, Barlucchi L, Torella D, et al. Adult cardiac stem cells are multipotent and support myocardial regeneration. Cell 2003; 114(6): 763-76.

[54] Urbanek K, Torella D, Sheikh F, et al. Myocardial regeneration by activation of multipotent cardiac stem cells in ischemic heart failure. Proc Natl Acad Sci U S A 2005; 102(24): 8692-97.

[55] Dawn B, Stein AB, Urbanek K, et al. Cardiac stem cells delivered intravascularly traverse the vessel barrier, regenerate infarcted myocardium, and improve cardiac function. Proc Natl Acad Sci U S A 2005; 102(10): 3766-71.

[56] Oh H, Bradfute SB, Gallardo TD, et al. Cardiac progenitor cells from adult myocardium: homing, differentiation, and fusion after infarction. Proc Natl Acad Sci U S A 2003; 100(21): 12313-8.

[57] Oyama T, Nagai T, Wada H, et al. Cardiac side population cells have a potential to migrate and differentiate into cardiomyocytes in vitro and in vivo. J Cell Biol 2007; 176(3): 329-41.

[58] Matsuura K, Nagai T, Nishigaki N, et al. Adult cardiac Sca-1positive cells differentiate into beating cardiomyocytes. J Biol Chem 2004; 279(12): 11384-91.

[59] Pfister O, Mouquet F, Jain M, et al. CD31- but Not CD31+ cardiac side population cells exhibit functional cardiomyogenic differentiation. Circ Res 2005; 97(1): 52-61.

[60] Martin CM, Meeson AP, Robertson SM, et al. Persistent expression of the ATP-binding cassette transporter, Abcg2, identifies cardiac SP cells in the developing and adult heart. Dev Biol 2004; 265(1): 262-75

[61] Messina E, De Angelis L, Frati G, et al. Isolation and expansion of adult cardiac stem cells from human and murine heart. Circ Res 2004; 95(9): 911-21.
[62] Smith RR, Barile L, Cho HC, et al. Regenerative potential of cardiosphere-derived cells expanded from percutaneous endomyocardial biopsy specimens. Circulation 2007; 115(7): 896-908.

[63] Laugwitz KL, Moretti A, Lam J, et al. Postnatal isl1+ cardioblasts enter fully differentiated cardiomyocyte lineages. Nature 2005; 433(7026): 647-53.

[64] Winitsky SO, Gopal TV, Hassanzadeh S, et al. Adult murine skeletal muscle contains cells that can differentiate into beating cardiomyocytes in vitro. PLoS Biol 2005; 3(4): 87.

[65] Tamaki T, Akatsuka A, Okada Y, et al. Cardiomyocyte formation by skeletal muscle-derived multi-myogenic stem cells after transplantation into infarcted myocardium. PLoS ONE 2008; 3(3): 1789.

[66] Menasche P: Skeletal myoblasts as a therapeutic agent. Prog Cardiovasc Dis 2007; 50(1): 7-17.

[67] Dowell JD, Rubart M, Pasumarthi KB, Soonpa MH, Field LJ Myocyte and myogenic stem cell transplantation in the heart. Cardiovasc Res 2003; 58(2): 336-50.

[68] Kinnaird T, Stabile E, Burnett MS, et al. Marrow-derived stromal cells express genes encoding a broad spectrum of arteriogenic cytokines and promote in vitro and in vivo arteriogenesis through paracrine mechanisms. Circ Res 2004; 94(5): 678-85.

[69] Gnecchi M, He H, Liang OD, et al. Paracrine action accounts for marked protection of ischemic heart by Akt-modified mesenchymal stem cells. Nat Med 2005; 11(4): 367-68.

[70] Kutschka I, Chen IY, Kofidis T, et al. Collagen matrices enhance survival of transplanted cardiomyoblasts and contribute to functional improvement of ischemic rat hearts. Circulation 2006; 114(1 Suppl): I167-173.

[71] Miyahara Y, Nagaya N, Kataoka M, et al. Monolayered mesenchymal stem cells repair scarred myocardium after myocardial infarction. Nat Med 2006; 12(4): 459-65.

[72] Solchaga LA, Tognana E, Penick K, et al. A rapid seeding technique for the assembly of large cell/scaffold composite constructs. Tissue Eng 2006; 12(7): 1851-63.

[73] Noiseux N, Gnecchi M, Lopez-Ilasaca M, et al. Mesenchymal stem cells overexpressing Akt dramatically repair infarcted myocardium and improve cardiac function despite infrequent cellular fusion or differentiation. Mol Ther 2006; 14(6): 840-50.

[74] Menasche P, Hagege AA, Scorsin M, et al. Myoblast transplantation for heart failure. Lancet 2001; 357(9252): 279-80.

[75] Menasche P, Hagege AA, Vilquin JT, et al. Autologous skeletal myoblast transplantation for severe postinfarction left ventricular dysfunction. J Am Coll Cardiol 2003; 41(7): 1078-83.

[76] Hagege AA, Marolleau JP, Vilquin JT, et al. Skeletal myoblast transplantation in ischemic heart failure: long-term follow-up of the first phase I cohort of patients. Circulation 2006; 114(1 Suppl): I108-13.

[77] Abraham MR, Henrikson CA, Tung L et al. Antiarrhythmic engineering of skeletal myoblasts for cardiac transplantation. Circ Res 2005; 97(2): 159-67.

[78] Chen M, Fan ZC, Liu XJ, et al. Effects of autologous stem cell transplantation on ventricular electrophysiology in doxorubicininduced heart failure. Cell Biol Int 2006; 30(7): 576-82.

[79] Biagini E, Valgimigli M, Smits PC, et al. Stress and tissue Doppler echocardiographic evidence of effectiveness of myoblast transplantation in patients with ischaemic heart failure. Eur J Heart Fail 2006; 8(6): 641-48.

[80] Gavira JJ, Herreros J, Perez A, et al. Autologous skeletal myoblast transplantation in patients with nonacute myocardial infarction: 1year follow-up. J Thorac Cardiovasc Surg 2006; 131(4): 799-804.

[81] Dib N, Michler RE, Pagani FD, et al. Safety and feasibility of autologous myoblast transplantation in patients with ischemic cardiomyopathy: four-year follow-up. Circulation 2005; 112(12): 1748-55.

[82] Siminiak T, Kalawski R, Fiszer D et al. Autologous skeletal myoblast transplantation for the treatment of postinfarction myocardial injury: phase I clinical study with 12 months of follow-up. Am Heart J 2004; 148(3): 531-37.

[83] Chachques JC, Herreros J, Trainini J, et al. Autologous human serum for cell culture avoids the implantation of cardioverterdefibrillators in cellular cardiomyoplasty. Int J Cardiol 2004; 95 Suppl 1: S29-33.

[84] Ince H, Petzsch M, Rehders TC, Chatterjee T, Nienaber CA. Transcatheter transplantation of autologous skeletal myoblasts in postin- 
farction patients with severe left ventricular dysfunction. J Endovasc Ther 2004; 11(6): 695-704.

[85] Smits PC, Van Geuns RJ, Poldermans D, et al. Catheter-based intramyocardial injection of autologous skeletal myoblasts as a primary treatment of ischemic heart failure: clinical experience with six-month follow-up. J Am Coll Cardiol 2003; 42(12): 206369.

[86] Siminiak T, Fiszer D, Jerzykowska O, et al. Percutaneous transcoronary-venous transplantation of autologous skeletal myoblasts in the treatment of post-infarction myocardial contractility impairment: the POZNAN trial. Eur Heart J 2005; 26(12): 1188-95.

[87] Menasche P, Alfieri O, Janssens S, et al. The Myoblast Autologous Grafting in Ischemic Cardiomyopathy (MAGIC) trial: first randomized placebo-controlled study of myoblast transplantation. Circulation 2008; 117(9): 1189-1200.

[88] Schachinger V, Assmus B, Britten MB, et al. Transplantation of progenitor cells and regeneration enhancement in acute myocardial infarction: final one-year results of the TOPCARE-AMI Trial. J Am Coll Cardiol 2004; 44(8): 1690-99.

[89] Fernandez-Aviles F, San Roman JA, Garcia-Frade J, et al. Experimental and clinical regenerative capability of human bone marrow cells after myocardial infarction. Circ Res 2004; 95(7): 742-48.

[90] Kuethe F, Richartz BM, Sayer HG, et al. Lack of regeneration of myocardium by autologous intracoronary mononuclear bone marrow cell transplantation in humans with large anterior myocardial infarctions. Int J Cardiol 2004; 97(1): 123-27.

[91] Britten MB, Abolmaali ND, Assmus B, et al. Infarct remodeling after intracoronary progenitor cell treatment in patients with acute myocardial infarction (TOPCARE-AMI): mechanistic insights from serial contrast-enhanced magnetic resonance imaging. Circulation 2003; 108(18): 2212-18.

[92] Assmus B, Schachinger V, Teupe C, et al. Transplantation of Progenitor Cells and Regeneration Enhancement in Acute Myocardial Infarction (TOPCARE-AMI). Circulation 2002; 106(24): 3009-17.

[93] Strauer BE, Brehm M, Zeus T, et al. Repair of infarcted myocardium by autologous intracoronary mononuclear bone marrow cell transplantation in humans. Circulation 2002; 106(15): 1913-18.

[94] Meyer GP, Wollert KC, Lotz J, et al. Intracoronary bone marrow cell transfer after myocardial infarction: eighteen months' followup data from the randomized, controlled BOOST (BOne marrOw transfer to enhance ST-elevation infarct regeneration) trial. Circulation 2006; 113(10): 1287-94.

[95] Schaefer A, Meyer GP, Fuchs M, et al. Impact of intracoronary bone marrow cell transfer on diastolic function in patients after acute myocardial infarction: results from the BOOST trial. Eur Heart J 2006; 27(8): 929-35.

[96] Wollert KC, Meyer GP, Lotz J, et al. Intracoronary autologous bone-marrow cell transfer after myocardial infarction: the BOOST randomised controlled clinical trial. Lancet 2004; 364(9429): 14148.

[97] Chen SL, Fang WW, Ye F, et al. Effect on left ventricular function of intracoronary transplantation of autologous bone marrow mesenchymal stem cell in patients with acute myocardial infarction. Am J Cardiol 2004; 94(1): 92-95.

[98] Bartunek J, Vanderheyden M, Vandekerckhove B, et al. Intracoronary injection of CD133-positive enriched bone marrow progenitor cells promotes cardiac recovery after recent myocardial infarction: feasibility and safety. Circulation 2005; 112 (9 Suppl): I178-83.

[99] Janssens S, Dubois C, Bogaert J, et al. Autologous bone marrowderived stem-cell transfer in patients with ST-segment elevation myocardial infarction: double-blind, randomised controlled trial. Lancet 2006; 367(9505): 113-21.
[100] Erbs S, Linke A, Schachinger V, et al. Restoration of microvascular function in the infarct-related artery by intracoronary transplantation of bone marrow progenitor cells in patients with acute myocardial infarction: the Doppler Substudy of the Reinfusion of Enriched Progenitor Cells and Infarct Remodeling in Acute Myocardial Infarction (REPAIR-AMI) trial. Circulation 2007; 116(4): 36674.

[101] Schachinger V, Erbs S, Elsasser A, et al. Intracoronary bone marrow-derived progenitor cells in acute myocardial infarction. $\mathrm{N}$ Engl J Med 2006; 355(12): 1210-21.

[102] Lunde K, Solheim S, Aakhus S, et al. Intracoronary injection of mononuclear bone marrow cells in acute myocardial infarction. $\mathrm{N}$ Engl J Med 2006; 355(12): 1199-09.

[103] Lunde K, Solheim S, Aakhus S, et al. Exercise capacity and quality of life after intracoronary injection of autologous mononuclear bone marrow cells in acute myocardial infarction: results from the Autologous Stem cell Transplantation in Acute Myocardial Infarction (ASTAMI) randomized controlled trial. Am Heart J 2007; 154(4): 710 711-18.

[104] Meluzin J, Janousek S, Mayer J, et al. Three-, 6-, and 12-month results of autologous transplantation of mononuclear bone marrow cells in patients with acute myocardial infarction. Int $\mathrm{J}$ Cardiol 2007; xxx

[105] Meluzin J, Mayer J, Groch L, et al. Autologous transplantation of mononuclear bone marrow cells in patients with acute myocardial infarction: the effect of the dose of transplanted cells on myocardial function. Am Heart J 2006; 152(5): 975 979-15.

[106] Lipinski MJ, Biondi-Zoccai GG, Abbate A, et al. Impact of intracoronary cell therapy on left ventricular function in the setting of acute myocardial infarction: a collaborative systematic review and meta-analysis of controlled clinical trials. J Am Coll Cardiol 2007; 50(18): 1761-67.

[107] Ince H, Petzsch M, Kleine HD, et al. Prevention of left ventricular remodeling with granulocyte colony-stimulating factor after acute myocardial infarction: final 1-year results of the Front-Integrated Revascularization and Stem Cell Liberation in Evolving Acute Myocardial Infarction by Granulocyte Colony-Stimulating Factor (FIRSTLINE-AMI) Trial. Circulation 2005; 112(9 Suppl): I73-80.

[108] Ince H, Petzsch M, Kleine HD, et al. Preservation from left ventricular remodeling by front-integrated revascularization and stem cell liberation in evolving acute myocardial infarction by use of granulocyte-colony-stimulating factor (FIRSTLINE-AMI). Circulation 2005; 112(20): 3097-106.

[109] Zohlnhofer D, Ott I, Mehilli J, et al. Stem cell mobilization by granulocyte colony-stimulating factor in patients with acute myocardial infarction: a randomized controlled trial. JAMA 2006; 295(9): 1003-10.

[110] Ripa RS, Jorgensen E, Wang Y, et al. Stem cell mobilization induced by subcutaneous granulocyte-colony stimulating factor to improve cardiac regeneration after acute ST-elevation myocardial infarction: result of the double-blind, randomized, placebocontrolled stem cells in myocardial infarction (STEMMI) trial. Circulation 2006; 113(16): 1983-92.

[111] Jorgensen E, Ripa RS, Helqvist S, et al. In-stent neo-intimal hyperplasia after stem cell mobilization by granulocyte-colony stimulating factor Preliminary intracoronary ultrasound results from a double-blind randomized placebo-controlled study of patients treated with percutaneous coronary intervention for ST-elevation myocardial infarction (STEMMI Trial). Int J Cardiol 2006; 111(1): 17477.

[112] Harada M, Qin Y, Takano H, et al. G-CSF prevents cardiac remodeling after myocardial infarction by activating the Jak-Stat pathway in cardiomyocytes. Nat Med 2005; 11(3): 305-11. 